\title{
Monopoly Learning Media: Education Media in Structure and Function of Plant Tissue Theory
}

\author{
Media Pembelajaran Monopoli: Media Edukasi Materi Struktur dan Fungsi \\ Jaringan Tumbuhan
}

\author{
Fitri Andriyani ${ }^{1}$, Rahma R. Saraswati ${ }^{2}$, Dina Melasari ${ }^{1}$, \\ Agustiani Putri ${ }^{2}$, Dadan Sumardani ${ }^{3 *}$ \\ ${ }^{1}$ Program Studi Pendidikan Biologi, FMIPA, Universitas Negeri Jakarta \\ ${ }^{2}$ Program Studi Pendidikan Matematika, FMIPA,Universitas Negeri Jakarta \\ ${ }^{3}$ Program Studi Pendidikan Fisika, FMIPA,Universitas Negeri Jakarta \\ Jalan Rawamangun Muka, RT.11/RW.14, Rawamangun, Jakarta Timur 13220 \\ *Email: dansu.sumardani@gmail.com
}

Diterima 10 Februari 2020 dan Disetujui 31 Maret 2020

\begin{abstract}
Abstrak
Materi biologi pada struktur dan fungsi jaringan tanaman adalah salah satu materi yang paling sulit dipahami siswa. Ini karena mempelajari materi ini secara rinci membutuhkan alat bantu (mikroskop) yang pengamatannya tidak selalu mudah dipahami oleh siswa. Selain itu, sejauh ini media pembelajaran dan metode yang digunakan kurang bervariasi. Berdasarkan masalah tersebut, diperlukan media pembelajaran yang dapat meningkatkan minat siswa dan pemahaman siswa dalam mempelajari struktur dan fungsi jaringan tanaman. Penelitian ini bertujuan untuk mengembangkan media pembelajaran pendidikan monopoli pada struktur dan fungsi jaringan tanaman di kelas VIII Sekolah Menengah Pertama. Penelitian pengembangan ini mengacu pada model ADDIE (Analyze, Design, Development, Implement, Evaluation). Struktur permainan monopoli yang dikembangkan terdiri dari beberapa peralatan permainan (termasuk: papan monopoli, satu set kartu hak kepemilikan, satu set kartu dana publik dan peluang, satu set uang dadu, dan panduan permainan). Adapun bidak dalam permainan ini adalah para siswa itu sendiri. Berdasarkan uji validasi ahli bahan, ditemukan bahwa persentase kesesuaian bahan dalam monopoli struktur dan fungsi jaringan tanaman adalah $70,83 \%$ atau cukup baik. Sementara itu, untuk tes validasi ahli media persentase kelayakan adalah 63,33\% atau cukup baik. Berdasarkan uji validasi diperoleh rata-rata $67,08 \%$ atau jika diartikan maka monopoli struktur dan jaringan tanaman cukup layak sebagai media pembelajaran
\end{abstract}

Kata Kunci: Biologi, Media Pembelajaran, Monopoli.

\begin{abstract}
Material structure and function of plant tissue is one of the most difficult material for students to understand. This is because studying this material in detail requires aids (microscopes) whose observations are not necessarily easily understood by students. In addition, so far the learning media and methods used are less varied. Based on the above statement, we need a learning media that can increase student interest and student understanding in learning the structure and function of plant tissue. So this study aims to develop a monopolistic educational learning media on the structure and function of plant tissue in class VIII of SMPN. This development research refers to the ADDIE model (Analyze, Design, Development, Implement, Evaluation). The monopoly game structure and plant network developed consists of several game equipment including: a monopoly board, a set of ownership rights cards, a set of public and opportunity fund cards, a set of money - dice, and a game guide. As for the pawns in this game are the students themselves. Based on the material expert validation test, it was found that the percentage of material suitability in the monopoly of the structure and function of plant tissue was $70.83 \%$ or quite decent. Meanwhile, for the media expert validation test the percentage of eligibility was $63.33 \%$ or quite decent. Based on the validation test obtained an average of $67.08 \%$ or if interpreted then the monopoly of the plant's structure and tissue is quitefeasible.
\end{abstract}

Keywords: Biology, Learning Media, Monopoly 


\section{PENDAHULUAN}

Materi struktur dan fungsi jaringan merupakan salah satu materi tersulit dalam pembelajaran biologi karena tidak dapat dilihat langsung dengan indera peserta didik. Media pembelajaran biologi untuk mempelajari struktur terkecil seperti sel telah berkembang dalam dekade terakhir. Guru biasanya menggunakan buku dan slide powerpoint untuk menjelaskan materi strukturdan fungsi jaringan, sehingga dapat membuat pembelajaran tidak menarik bagi peserta didik (Yumarlin, 2013). Oleh karena itu, guru harus dapat mengembangkan media pembelajaranyang komunikatif dan aplikatif.

Pendidik harus dapat banyak mengembangkan berbagai jenis media seperti menggunakan mobile learning untuk meningkatkan hasil belajar materi struktur sel (Setiawati et al., 2019), media komik bergambar pada materi sistem saraf (Wahyuningsih, 2012), dan monopoly games materi sistem endokrin (Herdani et al., 2015). Semua jenis pengembangan yang dilakukan membuktikan bahwa pembelajaran biologi dengan karakteristik materi yang tidak bisa dilihat dengan mata telanjang, harus dibantu dengan media pembelajaran visualisasi. Salah satu media yang mungkin dikembangkan dalam pembelajaran biologi adalah media menggunakan monopoli.

Organ pada tumbuhan yang terdiri dari beberapa jaringan, mirip seperti benua yang terdiri atas beberapa negara dalam permainan monopoli. Berdasarkan karakteristik tersebut, maka media monopoli tepat digunakan pada materi struktur dan jaringan tumbuhan. Selain itu, permainan monopoli juga memiliki kelebihan dimana permainan monopoli memerlukan kecerdasan, ketegasan, dan ketangkasan para pemain.Permainan monopoli dipilih karena secaraumum peserta didik telah mengetahui carabermain, sehingga memudahkan dalam penggunaannya. Sebagian besar penjelasan materi struktur dan fungsi jaringan menggunakan gambar dan banyak memuat konsep-konsep bersifat hafalan, sehingga gambar dan konsep itu dapat dipaparkan menggunakan permainan monopoli (Vikagustanti, 2014).

Selain terbukti dapat meningkatkan hasil belajar karena monopoli lebih familiar pada penerapan pada peserta didik. Di sisi lain, penggunaan media permainan dapat menciptakan pembelajaran yang aktif, tidak membosankan, meningkatkan pemahaman terhadap materi yang disajikan, dan menumbuhkan minatbelajar siswa. Salah satu media pembelajaran yangdapat digunakan dalam bentuk permainan adalah monopoli (Ramadhani et al., 2016; Herdani, 2015; Siskawati et al., 2016; Ratnawati, 2013; Machin, 2012).

Berbagai kelebihan dari media monopoli selanjutnya dikembangkan oleh peneliti melalui pengembangan monopoli pada materi struktur dan fungsi dari jaringan. Namun, media pembelajaran pada materi struktur dan fungsi jaringan belum tersedia, sehingga dibutuhkan pengembangan. Monopoli yang dikembangkan harus memperhatikan komponen materi dan komponen permainan sehingga media yang dihasilkan bersifat edukatif sekaligus rekreatif sehingga peserta didik diharapkan dapat belajar dimana dan kapan saja (Nurhikmah, et al., 2018). Salah satu penelitian sebelumnya yang berkaitan dengan bio monopoli pada materi rangka dan tulang terdapat kelemahan yang terletak pada kualitas cetak dari papan monopoli dan kartu yang masih kurang jelas (Suwarno, 2018).

Tujuan dari penelitian ini adalah mengembangkan media pembelajaran yang dapat menunjang pembelajaran biologi pada materi struktur dan fungsi jaringan yang dibuat berupa permainan (games) monopoli. Dengan demikian, untuk mendapatkan kesimpulan dari hasil pengembangan media pembelajaran ini, dilakukan pula validasi oleh ahli media dan ahli materi. Hasil dari penelitian ini diharapkan akan menjadi acuan dalam penelitian berikutnya.

\section{METODE}

Metode yang digunakan dalam penelitian ini adalah metode penelitian dan pengembangan. Penelitian pengembangan ini mengacu pada model ADDIE (Analyze, Design, Development, Implement, Evaluation). Penelitian ini dilakukan hanya sampai tahap Development (Pengembangan), karena tujuan penelitian ini hanya sebatas mengembangkan dan menghasilkan suatu media pembelajaran yang valid untuk diimplementasikan berdasarkan penilaian validator.Teknik pengumpulan data untuk analisis kebutuhan dilakukan dengan teknik wawancara kepada guru. Setelah itu, data-data pendukung yang digunakan untuk proses pengembangan media pembelajaran monopoli IPA dikumpulkan. Data pendukung 
tersebut diantaranya pengumpulan materi dari beberapa literatur yang berkaitan dengan struktur dan fungsi jaringan tumbuhan, sehingga diperoleh materi yang luas tetapi dikemas dengan padat.

Teknik analisis pengukuran data yang digunakan adalah menggunakan skala likert untuk mengetahui kelayakan media pembelajaran ini. Untuk keperluan analisis kuantitatif, jawaban diberi skor yang telah ditetapkan dengan skor angka, detail dapat dilihat pada tabel 1. berikut,

Tabel 1. Kategori Skor

\begin{tabular}{cc}
\hline Kategori & Skor \\
\hline Sangat Baik & 5 \\
Baik & 4 \\
Cukup & 3 \\
Kurang & 2 \\
Sangat Kurang & 1 \\
\hline
\end{tabular}

Presentase kelayakan dihitung dengan menggunakan rumus (Salsabila, 2019):

$\%$ Presentase kelayakan $=\frac{j u m l a h \text { skor total jawaban }}{\text { jumlah skor total maksimum tiap indikator }} \times 100 \%$

Jika nilai presentase kelayakan telah didapat maka selanjutnya adalah penunjukkan predikat kualitas dari produk yang dibuat berdasarkan skala pengukuran rating scale. Skala penunjukan rating scale adalah pengubahan data kualitatif menjadi kuantitatif. Dengan rating scale data mentah yang diperoleh berupa angka kemudian ditafsirkan dalam pengertian kualitatif (Sugiyono, 2016). Berikut tabel yang merupakan rating scale yang digunakan untuk penfsiran kelayakan produk:

Tabel 2. Kategori Kelayakan Berdasarkan Rating Scale

\begin{tabular}{cc}
\hline Skor dalam persen (\%) & Kategori Kelayakan \\
\hline $0-25 \%$ & Sangat Tidak Layak \\
$>25 \%-50 \%$ & Kurang Layak \\
$>50 \%-75 \%$ & Cukup Layak \\
$>75 \%-100 \%$ & Sangat Layak \\
\hline
\end{tabular}

\section{HASIL DAN PEMBAHASAN \\ Hasil Penelitian}

Pengembangan produk meliputi berbagai komponen. Pengembangan media ini didasarkan pada komponen materi dan komponen hiburan (lihat gambar 1.). Papan permainan monopoli dicetak dengan ukuran $2 \times 2 \mathrm{~m}^{2}$ dengan memuat 22 petak yang berisi mengenai jaringan-jaringan tumbuhan, 1 petak penjara serta 4 petak kesempatan dan 4 petak peluang. Di dalam kesempatan dan dana umum berisi kartu informasi yang dapat dijadikan referensi dalam menjawab pertanyaan, selain itu juga memuat kartu masuk penjara dan kartu bebas penjara. Selain itu pada papan monopoli juga terdapat petak penjara, bebas pilih dan start.

Pada berbagai permainan, telah didesain ketika mendapatkan Dana Umum pada Gambar 2.a maka peserta didik akan diberi pertanyaan tentang materi struktur dan jaringan tumbuhan, pada Gambar 2.b ketika mendapat kartu kesempatan maka yang mendapatkan kartu akan memberi pertanyaan biologi pada peserta lain. Sertifikat kepemilikan (Gambar 2.c) adalah sertifikat berisi harga setiap fungsi dari jaringan tumbuhan dan soal yang menjadi hak pembeli petak. Siswa yang membeli petak maka mendapat sertifikat kepemilikan sesuai dengan kategori petak. Siswa yang telah memiliki sertifikat kepemilikan mendapat kesempatan untuk melontarkan soalpada siswa lain yang berhenti pada petaknya. Selain itu, pada kartu ini terdapat denda yang harus dibayarkan oleh pihak lawan jika salah dalam menjawab soal. 


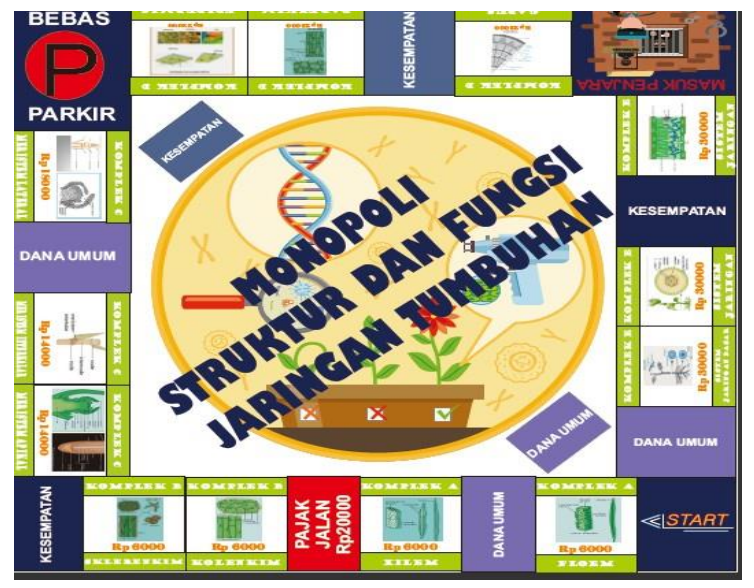

Gambar 1. Desain Papan Monopoli Umum

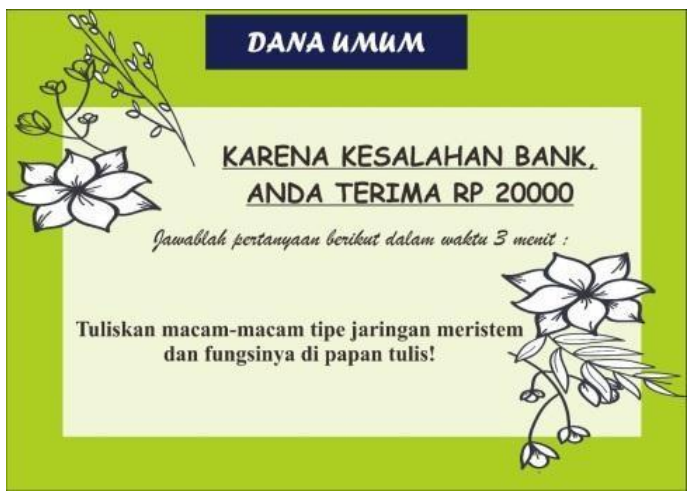

(a)

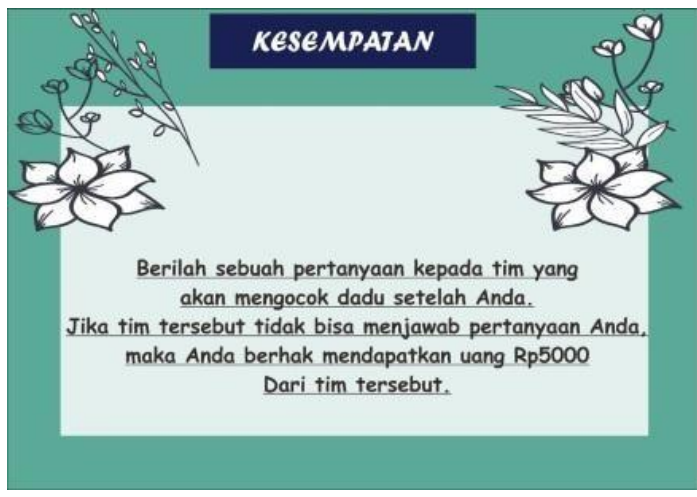

(b)

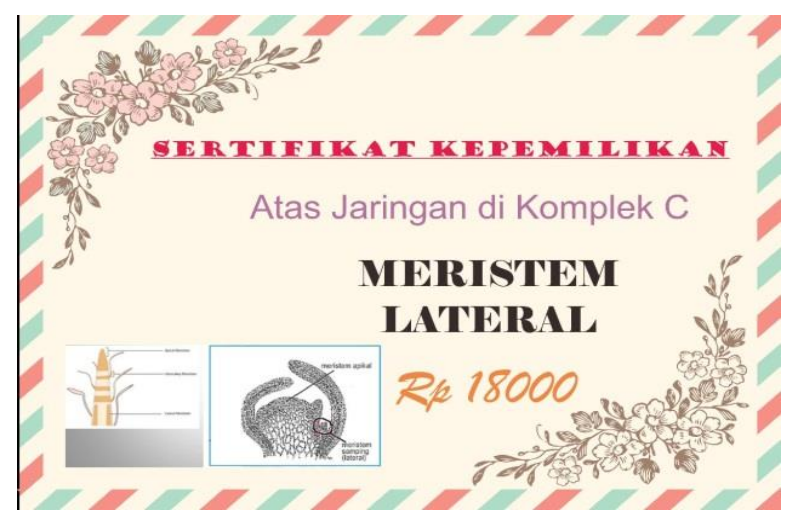

(c)

Gambar 2. Desain Kartu pada Monopoli a) Kartu Dana Umum, b) Kartu Kesempatan, c) Kartu Sertifikat Kepemilikan

Dalam permainan ini, purwarupa uang digunakan sebagai alat tukar, sehingga pemain dapat saling membeli, menjual, membayar, dan memberi kembalian. Uang - uang yang yang digunakan adalah uang mainan yang terlihat sama dengan uang sungguhan. Purwarupa uang dikembangkan dengan menggunakan jenis jenis jaringan meristem.

Permainan Monopoli ini memerlukan kecerdasan, ketegasan, dan ketangkasan para pemain dalam mengadakan transaksi kombinasi antara menyewakan, menjual dan membeli harga kekayaan hingga akhirnya salah seorang menjadi orang kaya mutlak atau disebut Monopolist. Permainan ini dimulai pada petak bagian "Start" dan berjalan seterusnya sesuai dengan angka - angka yang tertunjuk di batu dadu. Pemain yang berhenti di atas sebuah 
jaringan yang belum dimiliki oleh pemain lain, berhak membelinya dari bank dengan harga yang telah ditentukan pada papan permainan. Kalau pemain tersebut tidak berhasrat membeli jaringan tadi, maka bank berhak menjualnya kepada penawar tertinggi.

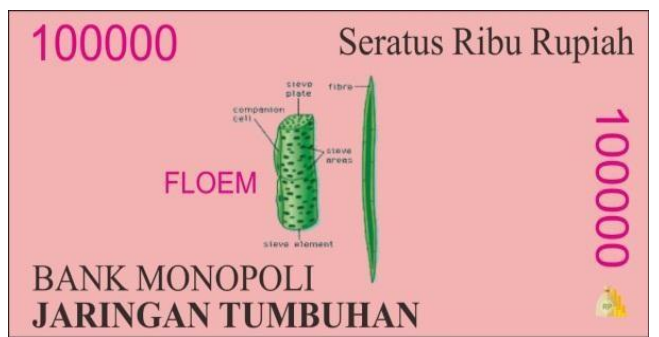

(a)

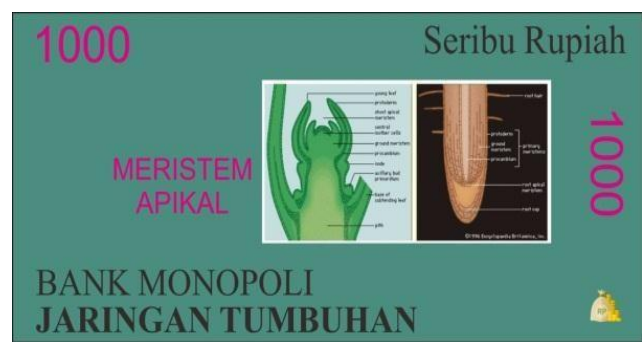

(b)

Gambar 3. Uang Pecahan yang digunakan pada permainan a) pecahan Rp 100.000 berisi gambar jaringan Floem, b) pecahan Rp 1.000 berisi gambar jaringan Meristem.

Tujuan utama memiliki jaringan sebanyak mungkin ialah memungut sewa dari pemain yang berhenti di atas tanah milik tersebut dan tidak bisa menjawab pertanyaan dari si pemilik jaringan. Uang sewa dapat dipungut lebih banyak lagi kalau fungsi dari jaringan tersebut dibeli secara lengkap. Akan tetapi, kalau sudah memiliki satu organ tumbuhan (lihat abjad/alphabet yang bersamaan), pemain diizinkan untuk membeli fungsi-fungsi jaringan tumbuhan.

Permainan monopoli pada media pembelajaran ini dilakukan dengan cara menyiapkan papan permainan di lantai, lalu menyusun kartu dana umum dan kesempatan dalam keadaan terbalik pada petak yang telah disediakan. Tiap pemain diberi uang Rp 200.000,-. Segala sertifikat jaringan diserahkan kepada bank. Penjabat bank dipilih seorang diantara pemain. Permulaan dimulai dengan guru memberikan tugas kepada siswa untuk menggambar salah satu struktur jaringan tumbuhan. Tim yang menggambar tercepat dan paling benar boleh melempar dadu terlebih dahulu. Begitu pula untuk menentukan giliran kedua dan ketiga. Permainan dimulai petak "Start". Setelah itu pion-pion dijalankan bergiliran, sesuai dengan angka dadu ke petak-petak menurut arah panah. Setiap akan mengocok dadu pemain wajib menjawab pertanyaan dari guru, jika tim tersebut tidak dapat menjawab pertanyaan dari guru maka tim tersebut tidak boleh mengocok dadu. Sebelum permainan dimulai para pemain bersama-sama boleh menentukan berapa jam permainan akan diakhiri pada akhir jam permainan, pemain yang terkaya dinyatakan sebagai pemenang.

\section{Pembahasan}

Penilaian atau uji produk oleh ahli materi dan ahli media dilakukan oleh ahli pada bidang materi dan media mata pelajaran biologi. Hal ini dilakukan untuk menilai tingkat validitas materi dan media produk yang dikembangkan. Hasil dari validasi media pembelajaran ditunjukkan pada Tabel 3.

Tabel 3. Hasil Validasi Ahli Materi dan Media

\begin{tabular}{clcc}
\hline \multicolumn{1}{c}{ No. } & \multicolumn{1}{c}{ Aspek } & Persentase Capaian & Interpretasi \\
\hline Hasil Validasi Ahli Materi & & \\
1. & Kesesuaian Materi & $80 \%$ & Sangat Layak \\
2. & Efisiensi & $80 \%$ & Sangat Layak \\
3. & Tampilan Monopoli & $50 \%$ & Kurang Layak \\
4. & Tampilan Komponen & $73,33 \%$ & Cukup Layak \\
\hline Rata-rata aspek materi yang diukur & $70,83 \%$ & Cukup Layak \\
\hline Hasil Validasi Ahli Media & & \\
1. & Kesesuaian Materi & $80 \%$ & Sangat Layak \\
2. & Efisiensi & $60 \%$ & Cukup Layak \\
3. & Tampilan Monopoli & $53,33 \%$ & Cukup Layak \\
4. & Tampilan Komponen & $60 \%$ & Cukup Layak \\
\hline
\end{tabular}




\begin{tabular}{lcc}
\hline Rata-rata aspek media yang diukur & $63,33 \%$ & Cukup Layak \\
\hline Hasil Validasi Ahli Secara Umum & & \\
1. Validasi Ahli Materi & $70,83 \%$ & Cukup Layak \\
2. Validasi Ahli Media & $63,33 \%$ & Cukup Layak \\
\hline Rata-rata seluruh aspek yang diukur & $67,08 \%$ & Cukup Layak \\
\hline
\end{tabular}

Berdasarkan hasil uji validasi kelayakan diperoleh rata-rata persentase capaian keseluruhan aspek sebesar $67,08 \%$. Berdasarkan interpretasi skala likert, hasil tersebut menunjukkan bahwa monopoli struktur dan fungsi jaringan tumbuhan yang dikembangkan cukup layak karena telah valid dari aspek materi, visualisasi, kebahasaan dan fungsi media. $\mathrm{Hal}$ ini menandakan bahwa produk tersebut layak untuk digunakan peserta didik dan guru karenadapat membantu dalam pembelajaran. Hal ini sejalan dengan penelitian sebelumnya yang menyatakan bahwa mediapermainan monopoli IPA dengan kategori yang sangat layak dapat digunakan sebagai mediapembelajaran (Susanto, 2012).

Validitas media monopoli untuk aspek materi telah direvisi agar memiliki kesesuaian pertanyaan dengan indikator kompetensi, kebenaran konsep materi dan pertanyaan serta kesesuaian kunci jawaban dengan pertanyaan. Setelah direvisi, media sudah dinyatakan valid dengan interpretasi sangat layak karena telah memenuhi cakupan KI, KD dan indikator pencapaian kompetensi yang sesuai Kurikulum 2013. Bahanajar yang dikembangkan harus sesuai dengan tuntunan kurikulum agar menghindari kesalahan pemahaman konsep-konsep bagi peserta didik (Depdiknas, 2008).

Validitas media monopoli untuk aspek tampilan telah direvisi dengan tambahan petak untuk tempat kartu kunci jawaban, tambahan kartu kunci jawaban untuk masingmasing kartu pertanyaan dan peraturan permainan serta beberapa isi dari kartu diganti dengan infobiologi. Pada validitas ini diperoleh kriteria valid dengan interpretasi cukup layak. Hal ini membuktikkan bahwa media monopoli yang dibuat sudah proporsional karena ukuran dan jenis huruf yang digunakan mudah dibaca, serta gambar dan ilustrasi dapat menarik bagi peserta didik. Sependapat dengan pernyataan bahwa penggunaan gambar pada bahan ajar dapat menambah daya tarik dan menghilangkan kebosanan peserta didik dalam mempelajarinya (Siskawati, 2016).

Hasil uji validitas media monopoli untuk aspek kebahasaandinyatakan valid dengan interpretasi cukup layak. Validitas ini telah mengalami beberapa revisi agar kalimat yang digunakan media pembelajaran ini efektif dan komunikatif terhadap peserta didik. Hal ini menunjukkan bahwa penggunaan bahasa yang dapat dipahami oleh peserta didik dan urutan petunjuk permainannya jelas. Sehubungan dengan itu,penelitian sebelumnya menyatakan bahwa, kalimat yang digunakan dalam bahan ajar harus jelas dan efektif (Rian, 2011).

Hasil uji validitas untuk aspek fungsi media dinyatakan valid. Hal ini menunjukkan bahwa media Montum yang dibuat memiliki empat fungsi dalam pembelajaran. Pertama, dapat menarik perhatian peserta didik untuk belajar karena didesain dengan penuh warna dan gambar yang menarik. Kedua, dapat meningkatkan daya ingat peserta didik melalui pertanyaan berulang pada kartu. Ketiga, seluruh pertanyaan dalam media dapat dijadikan bahan pemantapan materi. Keempat, dapat memupuk kerjasama pada peserta didik karena permainan dilakukan secara berkelompok dan terjadinya interaksi komunikasi antar pemain.

\section{KESIMPULAN}

Dari hasil penelitian yang telah dipaparkan dapat disimpulkan bahwa permainan monopoli struktur dan jaringan tumbuhan yang dikembangkan terdiri atas beberapa peralatan permainan diantaranya: papan monopoli, satu set kartu hak kepemilikan, satu set kartu dana umum dan kesempatan, satu set uang - uangan (purwarupa uang), dadu, dan panduan permainan. Adapun yang menjadi pion dalam permainan ini adalah para siswa itu sendiri. Berdasarkan uji validasi ahli materi didapatkan bahwa perentase kelayakan materi pada monopoli struktur dan fungsi jaringan tumbuhan adalah sebesar $70,83 \%$ atau tergolong cukup layak. Sedangkan, untuk uji validasi ahli media diperoleh persentase kelayakan sebesar $63,33 \%$ atau tergolong cukup layak. Berdasarkan uji validasi tersebut diperoleh persentase nilai rata-rata sebesar $67,08 \%$ atau jika interpretasikan maka monopoli struktur dan jaringan tumbuhan ini tergolong cukup layak untuk di jadikan sebagai media belajar yang menarik bagi siswa. 


\section{DAFTAR PUSTAKA}

Depdiknas.2008. Panduan Pengembangan Bahan Ajar. Jakarta: Direktorat Pembinaan SMA.

Harahap, HS. 2019. The Development of Biology Interactive Learning Media with Computer-Based Macromedia Flash of The Material Respiratory System of Human. Jurnal Pendidikan Biologi Nukleus, 5(2), 54-66.

Herdani, TP., Sartono N., Evriyani D. 2015. Pengembangan Permainan Monopoli Termodifikasi Sebagai Media Pembelajaran pada Materi Sistem Hormon (Penelitian dan Pengembangan di SMAN 1 Jakarta). Biosfer, 8(1), 20-28.

Machin, A. 2012. Pengaruh Permainan Call Cards Terhadap Hasil Belajar dan Aktivitas Pembelajaran Biologi. Jurnal Pendidikan IPA Indonesia, 1(2), 163-167.

Nurhikmah, H., Tahmir S., Junda M., Bena B A N. 2018. Blended Learning Media in Biology Classroom. Journal of Physics: Conf. Series, 1028 (012027).

Ramadhani, N., Wahyuni S., Handayani R D. 2016. Pengembangan Media Educational Game "Monopoli Fisika Asik (Mosik)" pada Mata Pelajaran. Jurnal Pembelajaran Fisika, 5(3), 235-245.

Ratnawati, R., Tjendrowaseno T I. 2013. Pembuatan Media Pembelajaran Biologi untuk Kelas VIII Sekolah Menengah Pertama Negeri 1 Tasikmadu. Seruni: Proceeding Seminar Riset Unggulan Nasional Informatika Dan Komputer, 2(1), 37-43.

Setiawati, DA., Setiati, N., Pribadi, T A. 2019. The Development of E-Atlas Learning Media Based on Mobile Learning on Cells. Journal of Biology Education, 8(1), 15-25.

Siskawati, M., Pargito, \& Pujiati. 2016. Pengembangan Media Pembelajaran Monopoli untuk Meningkatkan Minat Belajar Geografi Siswa. Jurnal Studi Sosial, 4(1), 72-80.

Salsabila, E., Rahayu W., Kharis SA., Putri A. 2019. Analysis of Mathematical Literacy on Students' Metacognition in Conic Section Material. Journal of Physics: Conference Series, 1417(1), 1-8.

Sumardani, D., Saraswati R R., Putri A., Bakri F., Muliyati D. 2020. System Implementation of Augmented Reality Application in Student Worksheet. Jurnal Informatika, 8(1), 1018.

Susanto, A. 2012. Permainan Monopolisebagai Media Pembelajaran Sub Materi Sel pada Siswa SMA kelas XI IPA. BioEdu, 1(1), 1-6.

Suwarno, RN., Suratsih. 2018. Pengembangan Media Educational Game "Bio-Monopoli" Sebagai Media Pembelajaran Submateri Rangka dan Tulang, Materi Sistem Gerak Untuk Siswa SMA/Ma Kelas XI IPA. Jurnal Prodi Pendidikan Biologi, 7(2), 102-113.

Syahrowardi., syahrowaerdi., Permana AH. 2016. Desain Handout Multimedia Menggunakan 3D Pageflip Professional untuk Media Pembelajaran pada Sistem Android. Jurnal Penelitian \& Pengembangan Pendidikan Fisika, 2(1), 89-96.

Vebrianto, R. 2011. The effect of multiplemedia instruction in improving studentsscience process skill and achievement.Procedia Social and Behavioral Sciences, 15(1), 346-350.

Vikagustanti, D A., Sudarmin., Pamelasari, S D. 2014. Pengembangan Media Pembelajaran Monopoli IPA Tema Organisasi Kehidupan Sebagai Sumber Belajar untuk Siswa SMP. Unnes Science Education Journal, 3(2), 468-475.

Wahyuningsih, A N. 2012. Pengembangan Media Komik Bergambar Materi Sistem Saraf untuk Pembelajaran yang Menggunakan Strategi PQ4R. Journal of Innovative Science Education, 1(1), 19-27. 